Jimena P. Cabilla, Sonia A. Ronchetti, Silvana I. Nudler, Eliana A. Miler, Fernanda A. Quinteros and Beatriz H. Duvilanski

Am J Physiol Endocrinol Metab 296:731-737, 2009. First published Jan 13, 2009;

doi:10.1152/ajpendo.90795.2008

You might find this additional information useful...

This article cites 28 articles, 10 of which you can access free at:

http://ajpendo.physiology.org/cgi/content/full/296/4/E731\#BIBL

Updated information and services including high-resolution figures, can be found at:

http://ajpendo.physiology.org/cgi/content/full/296/4/E731

Additional material and information about AJP - Endocrinology and Metabolism can be found at:

http://www.the-aps.org/publications/ajpendo

This information is current as of July 17, 2009 .

AJP - Endocrinology and Metabolism publishes results of original studies about endocrine and metabolic systems on any level of organization. It is published 12 times a year (monthly) by the American Physiological Society, 9650 Rockville Pike, Bethesda MD 20814-3991. Copyright @ 2005 by the American Physiological Society. ISSN: 0193-1849, ESSN: 1522-1555. Visit our website at http://www.the-aps.org/. 


\title{
Nitric oxide sensitive-guanylyl cyclase subunit expression changes during estrous cycle in anterior pituitary glands
}

\author{
Jimena P. Cabilla, Sonia A. Ronchetti, Silvana I. Nudler, Eliana A. Miler, Fernanda A. Quinteros, \\ and Beatriz H. Duvilanski \\ Departamento de Química Biológica, Instituto de Química y Fisicoquímica Biológicas, Facultad de Farmacia y Bioquímica, \\ Universidad de Buenos Aires, Buenos Aires, Argentina
}

Submitted 6 September 2008; accepted in final form 7 January 2009

Cabilla JP, Ronchetti SA, Nudler SI, Miler EA, Quinteros FA, Duvilanski BH. Nitric oxide sensitive-guanylyl cyclase subunit expression changes during estrous cycle in anterior pituitary glands. Am J Physiol Endocrinol Metab 296: E731-E737, 2009. First published January 13, 2009; doi:10.1152/ajpendo.90795.2008._-17ß-Estradiol $\left(\mathrm{E}_{2}\right)$ exerts inhibitory actions on the nitric oxide pathway in rat adult pituitary glands. Previously, we reported that in vivo $\mathrm{E}_{2}$ acute treatment had opposite effects on soluble guanylyl cyclase (sGC) subunits, increasing $\alpha_{1}$ - and decreasing $\beta_{1}$-subunit protein and mRNA expression and decreasing sGC activity in immature rats. Here we studied the $\mathrm{E}_{2}$ effect on $\mathrm{sGC}$ protein and mRNA expression in anterior pituitary gland from adult female rats to address whether the maturation of the hypothalamus-pituitary axis influences its effects and to corroborate whether these effects occur in physiological conditions such as during estrous cycle. $E_{2}$ administration causes the same effect on sGC as seen in immature rats, and these effects are estrogen receptor dependent. These results suggest that $\mathrm{E}_{2}$ is the main effector of these changes. Since the sGC $\alpha$-subunit increases while the sGC activity decreases, we studied if other less active isoforms of the sGC $\alpha$-subunit are expressed. Here we show for the first time that $\mathrm{sGC} \alpha_{2}$ and $\mathrm{sGC} \alpha_{2}$ inhibitory $\left(\alpha_{2 \mathrm{i}}\right)$ isoforms are expressed in this gland, but only sGC $\alpha_{2 i}$ mRNA increased after $E_{2}$ acute treatment. Finally, to test whether $\mathrm{E}_{2}$ effects take place under a physiological condition, sGC subunit expression was monitored over estrous cycle. $\mathrm{sGC} \alpha_{1},-\beta_{1}$, and $-\alpha_{2 i}$ fluctuate along estrous cycle, and these changes are directly related with $\mathrm{E}_{2}$ level fluctuations rather than to $\mathrm{NO}$ level variations. These findings show that $\mathrm{E}_{2}$ physiologically regulates $\mathrm{sGC}$ expression and highlight a novel mechanism by which $\mathrm{E}_{2}$ downregulates $\mathrm{sGC}$ activity in rat anterior pituitary gland.

estrogen; soluble guanylyl cyclase; inhibitory subunit

THE MAIN ESTROGENIC HORMONE $17 \beta$-estradiol $\left(\mathrm{E}_{2}\right)$ plays important regulatory roles in a broad variety of biological processes, acting mainly on reproductive tissues, bone, liver, pituitary, and brain $(9,25)$.

Nitric oxide (NO) is a signaling molecule that freely diffuses across cellular membranes where it binds to its main intracellular receptor, soluble guanylyl cyclase (sGC). This enzyme catalyzes the formation of cGMP from GTP. Subsequently, targets of cGMP such as cGMP-dependent protein kinases, cyclic nucleotide phosphodiesterases, and cyclic nucleotidesensitive ion channels are activated to continue the signal transduction $(15,18)$.

sGC is an heterodimeric enzyme and is comprised of two subunits, $\alpha$ and $\beta$, of which four types exist $\left(\alpha_{1}, \alpha_{2}, \beta_{1}\right.$, and

\footnotetext{
Address for reprint requests and other correspondence: B. H. Duvilanski, Departamento de Química Biológica, IQUIFIB, Facultad de Farmacia y Bioquímica, Universidad de Buenos Aires, Junín 956, Buenos Aires (C1113AAD), Argentina (e-mail: neuroend@ffyb.uba.ar).
}

$\beta_{2}$ ). Both $\alpha$-isoforms form a functional enzyme with the $\beta_{1}$-subunit, although the $\alpha_{1} \beta_{1}$ is the most abundant and widely expressed heterodimer, showing the greater activity $(12,13)$. The $\alpha_{2}$ is expressed in a more restricted pattern: in human tissues, it is present mainly in spleen, placenta, brain, and uterus; in rat, it was found in fetal brain (3). Furthermore, an inhibitory $\alpha_{2}$-subunit $\left(\alpha_{2 \mathrm{i}}\right)$ and many splicing variants of both isoforms of variable activity have also been identified $(1,22)$.

Reports indicate that $\mathrm{E}_{2}$ regulates the NO/sGC/cGMP pathway and the levels of NO and cGMP in many tissues. Several studies $(21,24)$ sustain an inhibitory role of $E_{2}$ on the $\mathrm{NO}$ pathway in pituitary gland. Pituitary glands from ovariectomized rats show increased NO synthase activity and mRNA and protein levels, whereas $\mathrm{E}_{2}$ treatment reverts this condition. These $E_{2}$ effects were only observed after in vivo treatment, and it has been suggested that they are indirect. In addition, it has been reported that $\mathrm{E}_{2}$ affects $\mathrm{SGC}$ expression and activity in uterus, PC12 cells, and hypothalamus (8, 10, 14). Previous studies from our laboratory (4) show that acute $\mathrm{E}_{2}$ treatment exerts an inhibitory effect on sGC by downregulating the ${ }_{s G C} \beta_{1}$ subunit and $\mathrm{sGC}$ activity but increases $\mathrm{sGC} \alpha_{1}$ expression in anterior pituitary gland from immature rats. $\mathrm{E}_{2}$ effects on anterior pituitary sGC were observed such after in vivo as in vitro treatment, suggesting a direct effect of $E_{2}$ on sGC regulation and a differential and independent regulation of both subunits. Previous evidence $(4,7)$ further sustains that under certain conditions $\alpha_{1}$ and $\beta_{1}$ can be independently regulated.

Taking into account preceding results, the aim of this work was to investigate whether $E_{2}$ affects $s G C$ subunit expression and activity on pituitary gland from adult rats and to corroborate whether these effects occur in physiological conditions such as during estrous cycle. Besides, since the sGC $\alpha$-subunit increases while sGC activity decreases, we studied the expression of other less active isoforms of the sGC $\alpha$-subunit in the anterior pituitary gland and whether they are regulated by $E_{2}$. To this end, we studied the in vivo effect of exogenous or endogenous $\mathrm{E}_{2}$ on sGC expression.

\section{MATERIALS AND METHODS}

\section{Materials}

The $7 \alpha, 17 \beta-\{9[(4,4,5,5,5$-pentafluoropentyl)sulfinyl $]$ nonyl $\}$ stra1,3,5(10)-triene-3,17-diol (ICI 182,780) was purchased from Tocris Neuramin (Bristol, UK). Z-1-[2-(2-aminoethyl)- $N$-(2-ammonioethyl)amino]diazen-1-ium-1,2-diolate (DETANONOate) was purchased from Cayman Chemical (Ann Arbor, MI). Leupeptin, pepsta-

\footnotetext{
The costs of publication of this article were defrayed in part by the payment of page charges. The article must therefore be hereby marked "advertisement" in accordance with 18 U.S.C. Section 1734 solely to indicate this fact.
} 
tin, PMSF, DTT, and diaminobenzidine were obtained from Alexis-US Biological (Swampscott, MA). Bradford reagent was purchased from Bio-Rad (Hercules, CA). Propylene glycol and hydrogen peroxide were from Cicarelli (Buenos Aires, Argentina). GoTaq DNA polimerase was provided by Promega (Madison, WI). TRIzol and molecular biology reagents were from Invitrogen (Carlsbad, CA). Media and reagents for cell culture were purchased from GIBCO (Rockville, MD), except for the FBS that was obtained from GBO (Buenos Aires, Argentina). Otherwise indicated, all other reagents and antibodies were obtained from Sigma-Aldrich (Buenos Aires, Argentina).

\section{Animals and treatments}

Adult female Wistar rats (180-200 g) were used. Animals were kept with controlled conditions of light (12:12-h light-dark cycle) and temperature $\left(21-24^{\circ} \mathrm{C}\right)$. Food and water were supplied ad libitum. All procedures were in accordance with the National Institutes of Health's Guide for the Care and Use of Laboratory Animals.

For $E_{2}$ acute effects experiments, rats were injected subcutaneously in the periscapular region with $40 \mu \mathrm{g} / \mathrm{kg}$ body wt $\mathrm{E}_{2}$ or with vehicle alone (propylene glycol) and killed over a time course. When required, animals were injected intraperitoneally with $2 \mathrm{mg} / \mathrm{kg}$ ICI $182,78030 \mathrm{~min}$ before $40 \mu \mathrm{g} / \mathrm{kg} \mathrm{E}$ administration.

Intact rats were monitored by daily (0800-0900) vaginal smears over three consecutive cycles. Animals at random stages of estrous cycle or at proestrus, estrus, or diestrus were killed by decapitation at 1700 .

\section{Ovariectomy}

Rats were ovariectomized under ketamine $(75 \mathrm{mg} / \mathrm{kg}$; HollidayScott, Buenos Aires, Argentina) and xylacine (10 mg/kg; König, Buenos Aires, Argentina) anesthesia 14 days before the experiments. Sham-operated rats were used as controls.

\section{Cell culture}

Primary cell culture was prepared from anterior pituitary glands from ovariectomized or sham rats killed at 14 days postsurgery. Anterior pituitary glands from each condition were pooled for each cell culture. Cells were obtained by enzymatic (trypsin/DNAse) and mechanical dispersion (extrusion through a Pasteur pipette). Cell viability was assessed by the trypan blue exclusion method. Dispersed cells were seeded onto tissue culture plates and stabilized for $48 \mathrm{~h}$ $\left(37^{\circ} \mathrm{C}, 5 \% \mathrm{CO}_{2}\right.$ in air) in phenol red-free DMEM supplemented with $10 \%$ charcoal stripped FBS, $10 \mu \mathrm{l} / \mathrm{ml}$ MEM amino acids, $2 \mathrm{mM}$ glutamine, $5.6 \mu \mathrm{g} / \mathrm{ml}$ amphotericin $\mathrm{B}$, and $25 \mu \mathrm{g} / \mathrm{ml}$ gentamicin.

\section{Cell treatment}

After the stabilization period, the medium was changed for fresh medium and cells were incubated during $6 \mathrm{~h}\left(37^{\circ} \mathrm{C}, 5 \% \mathrm{CO}_{2}\right.$ in air $)$ with or without $0.5 \mathrm{mM}$ DETANONOate. After treatment, RNA isolation from each condition was carried out.

\section{Immunoblot analysis}

Anterior pituitary glands were removed and sonicated in lysis buffer containing $10 \mathrm{mM}$ HEPES $\mathrm{pH} 7.4,150 \mathrm{mM} \mathrm{NaCl}, 10 \mathrm{mM}$ EDTA, $100 \mu \mathrm{M}$ leupeptin, $350 \mu \mathrm{M}$ pepstatin, $0.5 \mathrm{mM}$ PMSF, and 0.2 $\mathrm{mM}$ DTT. Sonicates were centrifuged for $20 \mathrm{~min}$ at $10,000 \mathrm{~g}$, and the soluble fraction was used in the immunoblot analysis. Protein content from the supernatants was measured by Bradford reagent, using BSA as a standard. Twenty to thirty micrograms of total protein from each sample were boiled for $5 \mathrm{~min}$ in Laemmli sample buffer and were fractioned on $10 \%$ SDS-PAGE. Resolved proteins were transferred to polyvinylidene difluoride membranes and blocked for $2 \mathrm{~d}$ at $4{ }^{\circ} \mathrm{C}$ in blocking buffer (TBS-0.05\% Tween 20 and 6\% nonfat dry milk). Then, membranes were coincubated overnight at $4^{\circ} \mathrm{C}$ with rabbit antisera anti-GC $\alpha_{1}(1: 1,750)$ or $\beta_{1}(1: 700)$ subunits and anti-actin $(1: 1,000)$ in blocking buffer. Then blots were washed and incubated for $1 \mathrm{~h}$ at room temperature with horseradish-peroxidase conjugated goat anti-rabbit $\operatorname{IgG}(1: 2,000)$, followed by detection of immunoreactivity with diaminobenzidine solution containing $0.01 \%$ hydrogen peroxide.

\section{RT-PCR and semiquantitative PCR}

RNA isolation. Tissues were removed and immediately homogenized with TRIzol reagent. After isolation, total RNA from tissues was spectrophotometrically quantified at $260 \mathrm{~nm}$. RNA integrity was checked in formaldehyde/formamide gel electrophoresis.

$R T$ and PCR reactions. First-strand cDNA was synthesized with Moloney murine leukemia virus RT in RT buffer containing $5.5 \mathrm{mM}$ $\mathrm{MgCl}_{2}, 0.5 \mathrm{mM} \mathrm{dNTP}, 2.5 \mu \mathrm{M}$ random hexamers, and $3.125 \mathrm{U} / \mu \mathrm{l}$ Moloney murine leukemia virus RT. Reactions were done in a final volume of $12 \mu \mathrm{l}$ containing $1 \mu \mathrm{g}$ RNA. The RT reaction was run at $37^{\circ} \mathrm{C}$ for $50 \mathrm{~min}$, and RT was inactivated by heating the samples at $70^{\circ} \mathrm{C}$ for $15 \mathrm{~min}$ before the PCR reactions. To check for genomic contamination, the same procedure was performed on samples in a reaction solution lacking $\mathrm{RT}$.

Specific primers for both subunits of sGC were designed from published sequences (23) with Oligo Perfect designer software (Invitrogen) and are detailed in Table 1 . The amplified products spanned from nucleotide position base 1,971 to 2,054 in the C-terminal region of $\mathrm{sGC} \alpha_{1}$, from $714-823$ in the $\mathrm{N}$-terminal region of $\mathrm{sGC} \beta_{1}$, from $1,530-1,929$ in the C-terminal region of $\mathrm{sGC}_{2}$, and from within the in-frame insert to $275 \mathrm{bp}$ to the $3^{\prime}$-end of $\mathrm{sGC} \alpha_{2 \mathrm{i}}$ (1). $\beta$-Actin was used as an endogenous control. Actin primers were designed to detect amplification of DNA contamination. Then, samples were thermocycled for PCR amplification (Mastercycler; Eppendorf, Hamburg, Germany). The reaction mixture contained GoTaq PCR buffer, 1.5 $\mathrm{mM} \mathrm{MgCl} 2,200 \mu \mathrm{M}$ of each dNTP, $0.625 \mathrm{U}$ GoTaq polymerase, and $300 \mathrm{nM}$ of each primer. RT-PCR methods were utilized to determine relative changes in mRNA expression. Reactions were subjected to a varying number $(n=16-40)$ of cycles of PCR amplification (melting phase $94^{\circ} \mathrm{C}$ for $30 \mathrm{~s}$, annealing $55^{\circ} \mathrm{C}$ for $30 \mathrm{~s}$, and extension $72^{\circ} \mathrm{C}$ for $1 \mathrm{~min}$ ) to find out the optimum cycle number within the linear range for PCR amplification. Amplified products collected at various cycles were analyzed by electrophoresis in $1.5 \%$ agarose-ethidium bromide gels, and the optimum cycle number resulted in 24 cycles for $\beta$-actin, 28 cycles for $s G C \alpha_{1}$ and $\beta_{1}$, and 40 cycles for $s G C \alpha_{2}$ and $s G C \alpha_{2 i}$.

\section{Analysis of semiquantitative PCR and immunoblot data}

The intensities of PCR products and immunoblot signals were determined by digital image analysis using the Gel Pro analyzer

Table 1. Primers used for semiquantitative RT-PCR assays

\begin{tabular}{|c|c|c|}
\hline Gene & Primer & Product Size \\
\hline \multicolumn{3}{|l|}{$\mathrm{sGC} \alpha_{1}$} \\
\hline Forward & 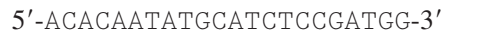 & \multirow[t]{2}{*}{$83 \mathrm{bp}$} \\
\hline Reverse & 5'-GCTCTCTATACTCGCTTTGACCAA-3' & \\
\hline \multicolumn{3}{|l|}{$\mathrm{sGC} \beta_{1}$} \\
\hline Forward & 5'-CCCGTGGAAACTGATGTCAA-3' & \multirow[t]{2}{*}{109 bp } \\
\hline Reverse & 5'-CGGGACCTAGTAGTCACGCA-3' & \\
\hline \multicolumn{3}{|l|}{$\mathrm{sGC} \alpha_{2}$} \\
\hline Forward & 5'-GCGACTGTCTACCCCGTTTGTGAT-3' & \multirow[t]{2}{*}{399 bp } \\
\hline Reverse & 5'-CTGTACTTGCTGCCCTTGCCATAA-3' & \\
\hline \multicolumn{3}{|l|}{$\mathrm{sGC} \alpha_{2 \mathrm{i}}$} \\
\hline Forward & 5'-тTтTстсстTTCстGTTTCСATCC-3' & \multirow[t]{2}{*}{$275 \mathrm{bp}$} \\
\hline Reverse & 5'-ACGAGACCGCGGAATGAATG-3' & \\
\hline \multicolumn{3}{|l|}{$\beta$-Actin } \\
\hline Forward & 5'-ACCACAGCTGAGAGGGAAATCG-3' & \multirow[t]{2}{*}{$276 \mathrm{bp}$} \\
\hline Reverse & 5'-AGAGGTCTTTACGGATGTCAACG-3' & \\
\hline
\end{tabular}

sGC, soluble guanylyl cyclase; i, inhibitory isoform. 
(Media Cybernetics, Silver Spring, MD) software for Windows. To allow statistical comparison of results from different experiments, sGC subunits levels were normalized to the value of the $\beta$-actin amplified band in each lane or to the actin immunoreactive band, respectively.

\section{Intracellular cGMP determination}

Anterior pituitary glands were quickly removed and placed on dry ice. Subsequently, they were sonicated in warm $50 \mathrm{mM}$ sodium acetate $\mathrm{pH} 6.2$, boiled for $10 \mathrm{~min}$, and centrifuged at 10,000 $\mathrm{g}$ for 10 min. Supernatants were stored at $-70^{\circ} \mathrm{C}$ until cGMP determination. Cyclic GMP was assayed as previously described (2) by specific RIA using rabbit anti-cGMP polyclonal antiserum and acetylated cGMP as standard. Total protein content in the pellets was measured as described above.

\section{Statistical analysis}

Results are expressed as means \pm SE and were evaluated by one-way ANOVA followed by Dunnett's, Tukey's, or Student's $t$-test, depending on the experimental design. Differences between groups were considered significant if $P<0.05$. Results were confirmed by at least three independent experiments.

\section{RESULTS}

$E_{2}$ Administration Increased $s G C \alpha_{1}$ and Decreased $s G C \beta_{1}$ Protein and mRNA Expression in Anterior Pituitary Glands of Adult Female Rats, Decreasing cGMP Production

To Identify Whether the Maturation of the Hypothalamuspituitary axis influences $E_{2}$ effects on $\mathrm{SGC}$ subunits, we studied the influence of a physiological dose of $\mathrm{E}_{2}(4,14)$ on $\mathrm{sGC}$ subunit expression in adult female rats. Rats at random estral stages ( $n=5$ per group) received a single dose of $10^{-9} \mathrm{M} \mathrm{E}_{2}$ and were killed over a time course. As seen previously in immature rats (4), in vivo administration of $E_{2}$ resulted in an increase of $\mathrm{sGC}_{1}$ levels and, concomitantly, a decrease in sGC $\beta_{1}$ protein levels. These effects became evident as soon as $4 \mathrm{~h}$ after $\mathrm{E}_{2}$ administration and were maximal at $8 \mathrm{~h}$ (relative units as percentage of control, $8-\mathrm{h} \mathrm{E}_{2} ; \mathrm{sGC}_{1}: 143 \pm 11$ and sGC $\beta_{1}: 79 \pm 8 ; P<0.05$, ANOVA followed by Dunnett's test). Protein levels of both subunits tended to return to control values after $12-16 \mathrm{~h}$ post- $\mathrm{E}_{2}$ injection (data not shown). Since these changes in protein expression could respond to altered mRNA synthesis, we evaluated then the action of $\mathrm{E}_{2}$ on $\mathrm{sGC} \alpha_{1}$ and $\mathrm{sGC} \beta_{1}$ mRNA expression by semiquantitative PCR. At 4and $8-\mathrm{h}$ post- $\mathrm{E}_{2}$ injection, $\mathrm{sGC}_{1}$ mRNA was significantly augmented respect to control values (Fig. 1). At the same time points, $\mathrm{sGC} \beta_{1}$ mRNA levels were diminished, consistent with the observed at protein level. These findings indicate that the differences observed at the protein level are consequence of effects at the transcription level.

Given that both subunits are required at 1:1 stoichiometry to have cGMP-producing activity, cGMP production was measured at different times. sGC activity was significantly reduced after $8 \mathrm{~h}$ of treatment with $\mathrm{E}_{2}$ [concentration of GMP (fmol/mg prot); means $\pm \mathrm{SE}$; control: $160 \pm 23, \mathrm{E}_{2} 4 \mathrm{~h}: 220 \pm 38$, and $\mathrm{E}_{2} 8$ h: $98 \pm 21 ; P<0.05$ vs. control, ANOVA followed by Dunnett's test; $n=3$ ], when the difference between subunit expression became maximal (data not shown). These results suggest that, independently of $\mathrm{sGC}_{1}$ subunit increase, $\mathrm{E}_{2}$ mediated downregulation of $\beta_{1}$ would be enough to decrease cGMP in the pituitary.

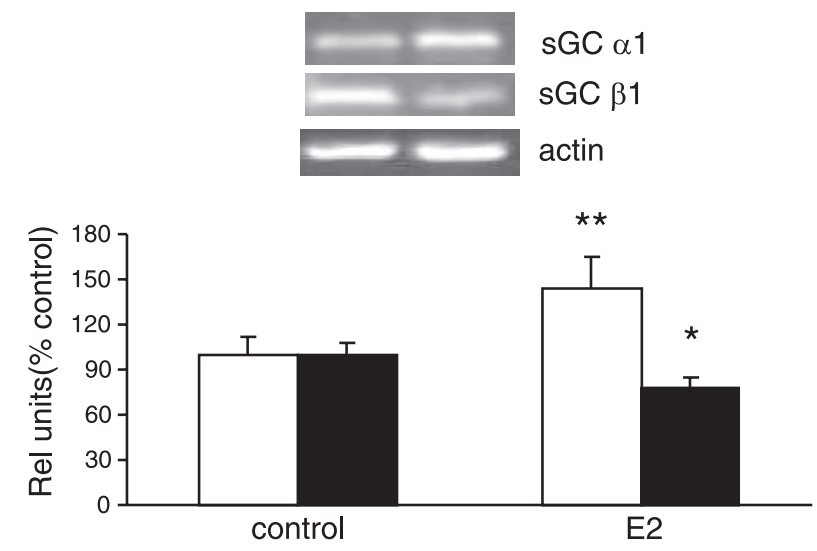

Fig. 1. Acute $\mathrm{E}_{2}$ treatment increases $\alpha_{1}$ soluble guanylyl cyclase (sGC) but decreases $\beta_{1}$ sGC mRNA expression in rat anterior pituitary gland. Adult intact rats at random stages of estrous cycle ( $n=5$ per group) were injected subcutaneous with $40 \mu \mathrm{g} / \mathrm{kg}$ body wt $\mathrm{E}_{2}$ and killed after $8 \mathrm{~h}$. Top: representative semiquantitative PCR. Bottom: average densitometric values. Bars are means $\pm \mathrm{SE}$ of the densitometric values of $\mathrm{sGC}_{1}$ (open bars) and $\mathrm{sGC} \beta_{1}$ (solid bars) mRNA densitometric values normalized to actin, as percentage of control $(n=5)$. $* P<0.05, * * P<0.01$ vs. control, ANOVA followed by Dunnett's test.

\section{$E_{2}$ effects are estrogen receptor dependent}

Next, to test if the actions of $\mathrm{E}_{2}$ on $\mathrm{sGC}$ subunits levels were specific, rats were injected with the pure estrogen receptor (ER) antagonist ICI 182,780 (2 $\mathrm{mg} / \mathrm{kg}$ ip) $30 \mathrm{~min}$ before $\mathrm{E}_{2}$ administration and killed after $8 \mathrm{~h}$. The antagonist had no effect by itself, but when coadministered with $\mathrm{E}_{2}$, it was able to completely avoid $\mathrm{E}_{2}$ effects on both $\mathrm{s} G \mathrm{C}$ subunit protein levels (Fig. 2). This observation indicates that the $\mathrm{E}_{2}$ effects on $\mathrm{sGC}$ expression are mediated by ER activation.

$E_{2}$ acute treatment increases the expression of the inhibitory subunit $\alpha_{2 i}$

It is known that other isoforms of $\mathrm{sGC} \alpha$ are expressed in different tissues. To date, the presence of these isoforms was not reported in pituitary gland. In our case, the augment registered in $\mathrm{sGC} \alpha_{1}$ protein as well as in mRNA could be due to an increase in $\alpha_{1}$ and/or to other less active or inhibitory isoforms of $\mathrm{sGC} \alpha$. In the present work, the anti-sGC $\alpha_{1}$ antibody utilized for immunoblot studies, as well as the primers used to amplify sGC $\alpha_{1}$ mRNA, was directed to the C-terminal sequence of rat $\mathrm{sGC} \alpha_{1}$ and it cannot differentiate among $\mathrm{sGC} \alpha$ species, since all of them include this sequence. To examine if these subunits are expressed in this tissue, we performed RT-PCR to detect $s G C \alpha_{2}$ and $\alpha_{2 i}$, using specific primers and liver and kidney or spleen as control tissues, respectively. Here we show for the first time that $\mathrm{sGC} \alpha_{2}$ and $\alpha_{2 \mathrm{i}}$ are expressed in anterior pituitary gland (Fig. 3A). Then, to investigate if their expression was modified by $\mathrm{E}_{2}$ treatment, rats were treated with a single dose of $E_{2}$ and killed after $6 \mathrm{~h}$. $\mathrm{E}_{2}$ treatment did not modify $\alpha 2$ mRNA expression respect to control, but $\alpha_{2 \mathrm{i}}$ mRNA levels were dramatically increased (relative units as percentage of control; sGC $\alpha_{2}$ control: $100 \pm 24 ; \mathrm{E}_{2} 8 \mathrm{~h}: 94 \pm$ 30; sGC $\alpha_{2 \mathrm{i}}$ control: $100 \pm 18$; and $\mathrm{E}_{2} 8 \mathrm{~h}$ : 1,730 $\pm 105 ; P<$ 0.001 , Dunnett's test; $n=3$; Fig. $3 B$ ). Again, to verify if this effect was $E_{2}$ specific, rats were injected intraperitoneally with $2 \mathrm{mg} / \mathrm{kg}$ ICI 182,780 $30 \mathrm{~min}$ before $\mathrm{E}_{2}$ subcutaneous administration, and killed over $8 \mathrm{~h}$. The inhibitor was able to fully 

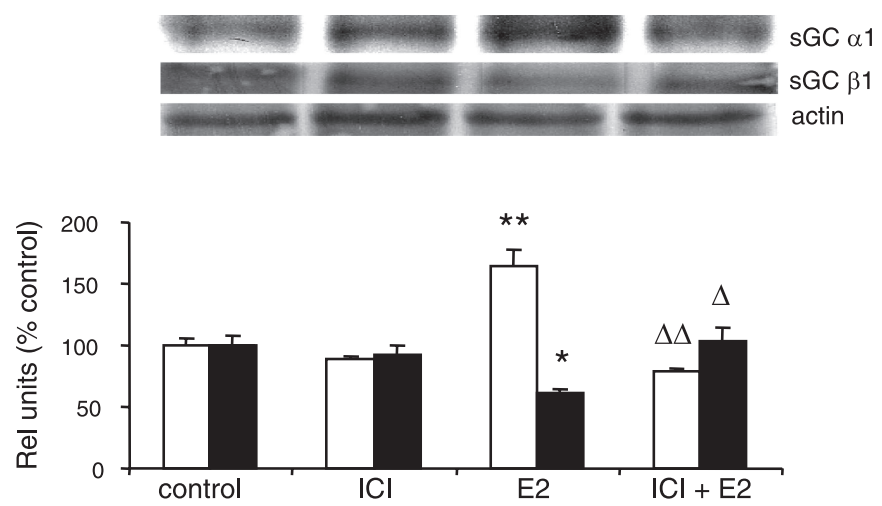

Fig. 2. $\mathrm{E}_{2}$ actions on $\mathrm{sGC}$ protein expression are abolished by pure antiestrogenic ICI 182,780 pretreatment in rat anterior pituitary gland. Adult intact rats at random stages of estrous cycle $(n=5$ per group) were injected subcutaneous with $2 \mathrm{mg} / \mathrm{kg}$ ICI 182,780 (ICI) $30 \mathrm{~min}$ before $40 \mu \mathrm{g} / \mathrm{kg}$ body wt $\mathrm{E}_{2}$ injection and killed after 8 h. Top: representative Western blot. Bottom: average densitometric values. Bars represent media $\pm \mathrm{SE}$ of the densitometric values of $\mathrm{sGC} \alpha_{1}$ (open bars) and $\mathrm{sGC} \beta_{1}$ (solid bars) protein levels normalized to actin, as percentage of control $(n=3)$. $* P<0.05$, $* * P<0.01$ vs. respective controls; ${ }^{\Delta} P<0.05,{ }^{\Delta \Delta} P<0.01$ vs. $E_{2}$, ANOVA followed by Dunnett's test.

abolish $\alpha_{2 \mathrm{i}}$ expression increase and had no effect per se on $\mathrm{sGC}_{2 \mathrm{i}}$ (Fig. 3C). Thus the augmented sGC $\alpha$ expression may reflect $\alpha_{1}$-increased levels but also an augmented $\alpha_{2 \mathrm{i}}$ expression. These findings suggest that both $\beta_{1}$ downregulation and $\alpha_{2 i}$-augmented expression could contribute to the acute inhibitory effect of $\mathrm{E}_{2}$ on sGC.

\section{$s G C$ subunit expression levels are variable through estrous cycle}

Taking into account the acute $\mathrm{E}_{2}$ actions on sGC expression and activity and to examine whether these effects occur under physiological conditions, we studied the changes on sGC through estrous cycle, a condition where $\mathrm{E}_{2}$ and also gonadotrophins, prolactin, and other gonadal steroids undergo rapid, dramatic changes. To this end, rats were killed on the afternoon (1700) of each stage of the estrous cycle and sGC protein levels were analyzed by Western blot. Protein levels of $\mathrm{sGC}_{1}$ showed a significant increase through the cycle from proestrus to diestrus (Fig. $4 A$ ). $\mathrm{sGC} \beta_{1}$ protein levels, which were higher than $\mathrm{sGC} \alpha_{1}$ on the afternoon of proestrus, did not change during estrus but significantly decreased at diestrus. Similar results were observed when sGC $\alpha_{1}$ and $\beta_{1}$ mRNA expression was evaluated by RT-PCR (data not shown). These findings show that sGC subunits levels independently fluctuate in vivo during estrous cycle. These individual variations of sGC subunit expression are consequence of hormonal changes taking place during estrous cycle, because in male rats and in ovariectomized rats both subunits show similar mRNA levels (relative units expressed as means $\pm \mathrm{SE} ; n=3$; male sGC $\alpha_{1}$ : $1.41 \pm 0.15$ and $\mathrm{sGC} \beta_{1}: 1.54 \pm 0.2$; and 14-day ovariectomized $\mathrm{sGC} \alpha_{1}: 1.43 \pm 0.42$ and $\left.\mathrm{sGC} \beta_{1}: 1.61 \pm 0.23\right)$.

\section{$s G C \alpha_{2 i}$ expression levels are variable through the estrous cycle}

Bearing in mind our findings showing that $\mathrm{sGC} \alpha_{1}$ expression increases over the cycle in spite of the decrease in cGMP production, the $\mathrm{sGC} \alpha_{2 \mathrm{i}}$ contribution to global expression was addressed. In accordance with the enhanced sGC activity on proestrus, $\alpha_{2 \mathrm{i}}$ mRNA expression was the lowest at this stage (Fig. $4 B$ ). On estrus and diestrus, $\alpha_{2 \mathrm{i}}$ expression was significantly augmented, which correlates with a lesser cGMP production. Altogether, the difference between sGC subunit expression according to the stage of the estrous cycle in which the animals were killed suggests the cyclicity of the response.

\section{Role of $N O$ on $s G C$ subunit expression}

NOS I protein and activity are strikingly upregulated on the afternoon of proestrus, and both return to basal levels after the afternoon of estrous, remaining low on diestrus I and II. cGMP production strongly correlates with NOS I upregulation (17). To determine if the changes seen in sGC subunit protein levels were due to changes in NO levels, we studied the in vitro effect of a short-time $\mathrm{NO}$ and $\mathrm{E}_{2}$ exposition on $\mathrm{SGC}$ protein expression. Pituitary cell cultures from intact adult female rats were incubated with $0.1 \mathrm{mM}$ DETANONOate, a NO donor, or $10^{-9}$ $\mathrm{M} \mathrm{E}_{2}$ for $6 \mathrm{~h}$, and $\mathrm{sGC} \alpha_{1}$ and $\beta_{1}$ expression was evaluated by Western blot. NO treatment upregulated both subunits in a

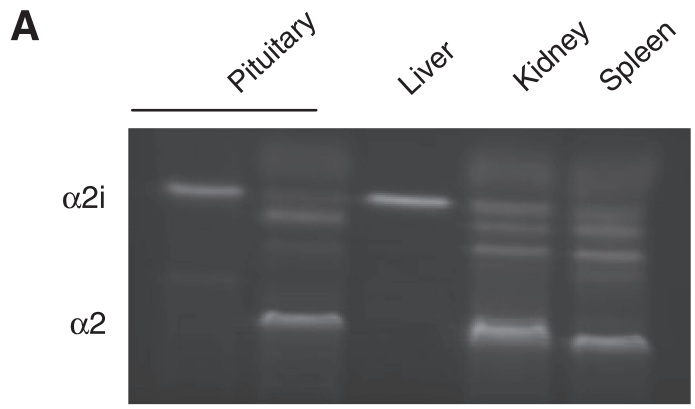

B
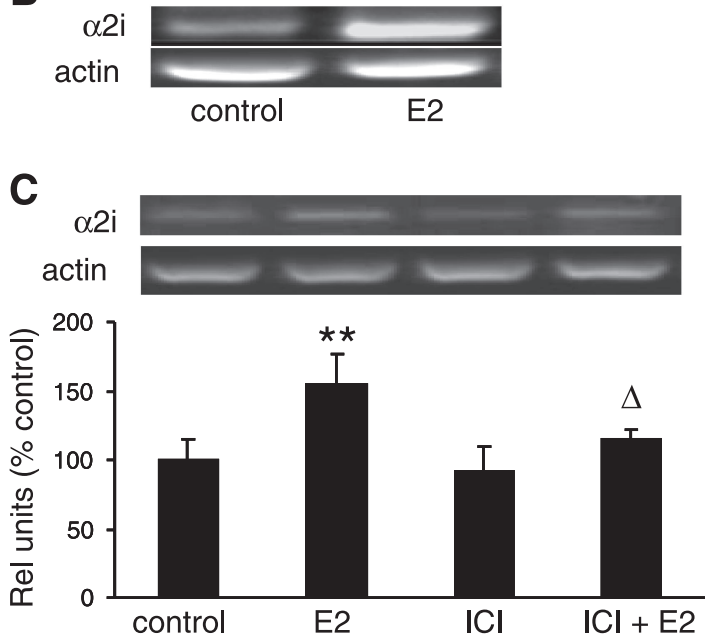

Fig. 3. Other isoforms of $\mathrm{sGC} \alpha$ are expressed normally in rat anterior pituitary gland. A: representative PCR showing the presence of $\mathrm{sGC} \alpha_{2}$ and $\alpha_{2 \mathrm{i}}$ mRNAs in anterior pituitary. Liver, kidney, and spleen were used as respective control tissues. $B$ : acute $E_{2}$ exposition increases the mRNA expression of the dominant negative isoform $\mathrm{sGC} \alpha_{2 \mathrm{i}}$. Animals were injected with $40 \mu \mathrm{g} / \mathrm{kg}$ body wt $\mathrm{E}_{2}$

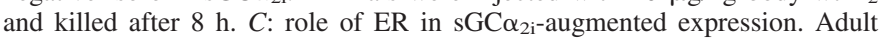
intact rats at random stages of estrous cycle ( $n=3$ per group) were injected intraperitoneally with $2 \mathrm{mg} / \mathrm{kg}$ ICI $182,78030 \mathrm{~min}$ before $40 \mu \mathrm{g} / \mathrm{kg}$ body wt $\mathrm{E}_{2}$ injection and killed after $8 \mathrm{~h}$. Bars are means $\pm \mathrm{SE}$ of the densitometric values of $\mathrm{sGC} \alpha_{i}$ mRNA normalized to actin, as percentage of control $(n=3)$. $* P<0.05$ vs control; ${ }^{\Delta} P<0.05$ vs. $\mathrm{E}_{2}$, ANOVA followed by Tukey's test. 
A
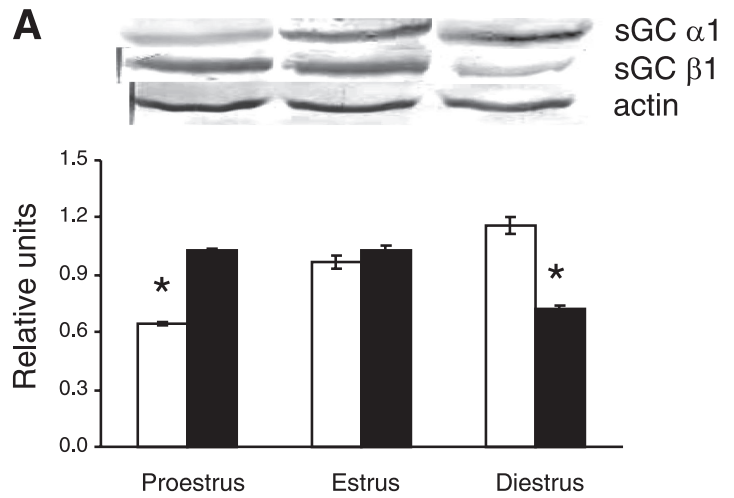

B

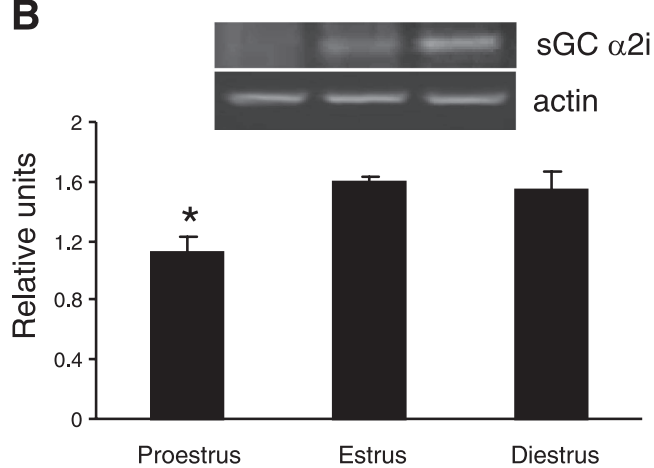

Fig. 4. sGC subunit expression fluctuates over estrous cycle. Rats $(n=3$ per group) were killed at 1700 on proestrus, estrus, or diestrus. A, top: a representative Western blot; bottom: average densitometric values. Bars are means $\pm \mathrm{SE}$ of $\mathrm{sGC} \alpha_{1}$ (open bars) and $\mathrm{sGC} \beta_{1}$ (solid bars) protein values normalized to actin $(n=3)$. ${ }^{*} P<0.05$ vs. estrus, ANOVA followed by Tukey's test. B, top: a representative PCR of $\mathrm{sGC}_{2 \mathrm{i}}$; bottom: average densitometric values. Bars are means $\pm \mathrm{SE}$ of $\mathrm{sGC}_{2 \mathrm{i}} \mathrm{mRNA}$ levels normalized to actin $(n=3)$. ${ }^{*} P<0.05$ vs. estrus and diestrus, ANOVA followed by Tukey's test.

similar fashion (Fig. 5A) while $\mathrm{E}_{2}$ treatment increased $\alpha_{1}$ but decreased $\beta_{1}$ expression (Fig. 5B). In addition, $\mathrm{sGC} \alpha_{1}$ and $-\beta_{1}$ expression was studied in the anterior pituitary glands of 14-day ovariectomized rats when NOS I protein and activity were markedly upregulated. At this condition, the results were similar to those with the NO donor in vitro (relative units as percentage of control; sGC $\alpha_{1}: 120.7 \pm 7.5$ and $\mathrm{sGC} \beta_{1}$ : $126 \pm 10.7 ; P<0.05$, ANOVA followed by Dunnett's test; $n=3)$. Thus short-time in vitro NO treatment or chronic in vivo $\mathrm{NO}$ increase did not mimic the effect of $\mathrm{E}_{2}$ in vitro or those seen in vivo during estrous cycle on sGC subunits. These results suggest again that the imbalance of sGC subunit expression is likely due to hormonal fluctuations rather than to NO.

\section{DISCUSSION}

Here we have shown that $\mathrm{E}_{2}$ causes the same effect on sGC subunits in adult and juvenile female animals, suggesting that these effects are distinctive of $E_{2}$ and independent of the hormonal fluctuation during the maturation of the reproductive axis. In vivo $\mathrm{E}_{2}$ acute treatment exerted opposite actions on both sGC subunits, increasing $s G C \alpha_{1}$ mRNA and protein levels and, simultaneously, decreasing sGC $\beta_{1}$ mRNA and protein levels. These effects were $\mathrm{E}_{2}$ specific and ER depen- dent. Our results also demonstrate that $\alpha$ - and $\beta$-subunit levels are independently modified. Different authors have previously reported that under certain conditions $\alpha$ - and $\beta$-subunits can be individually regulated. A complete loss of the $\beta_{1}$-subunit in aortic smooth muscle cells from old rats has been found, while the $\alpha$-subunit is still present (7). In developing rat brain, only sGC $\alpha$ mRNA is expressed, while sGC $\beta_{1}$ is totally absent (26), raising interesting questions regarding the independent functions of each subunit.

We have demonstrated that $E_{2}$ acute treatment enhanced $\alpha 1$ mRNA and protein expression but decreased sGC activity. It is known that fully active sGC requires $\alpha$ - and $\beta$-subunits in a strict 1:1 stoichiometry, and, even considering that $\alpha_{1}$ expression was increased, $\mathrm{sGC} \beta_{1}$ downregulation would be enough to reduce sGC global activity. However, the higher expression of $\alpha \mathrm{GC}$ could be due, at least in part, to an increased expression of other $\alpha$-isoforms with less activity. In the present work, we have demonstrated for the first time that $\mathrm{sGC} \alpha_{2}$ and $\mathrm{sGC} \alpha_{2 \mathrm{i}}$ isoforms are expressed in anterior pituitary gland and that after $\mathrm{E}_{2}$ stimulus $\mathrm{sGC} \alpha_{2 \mathrm{i}}$ expression (but not $\alpha_{2}$ ) is augmented. The
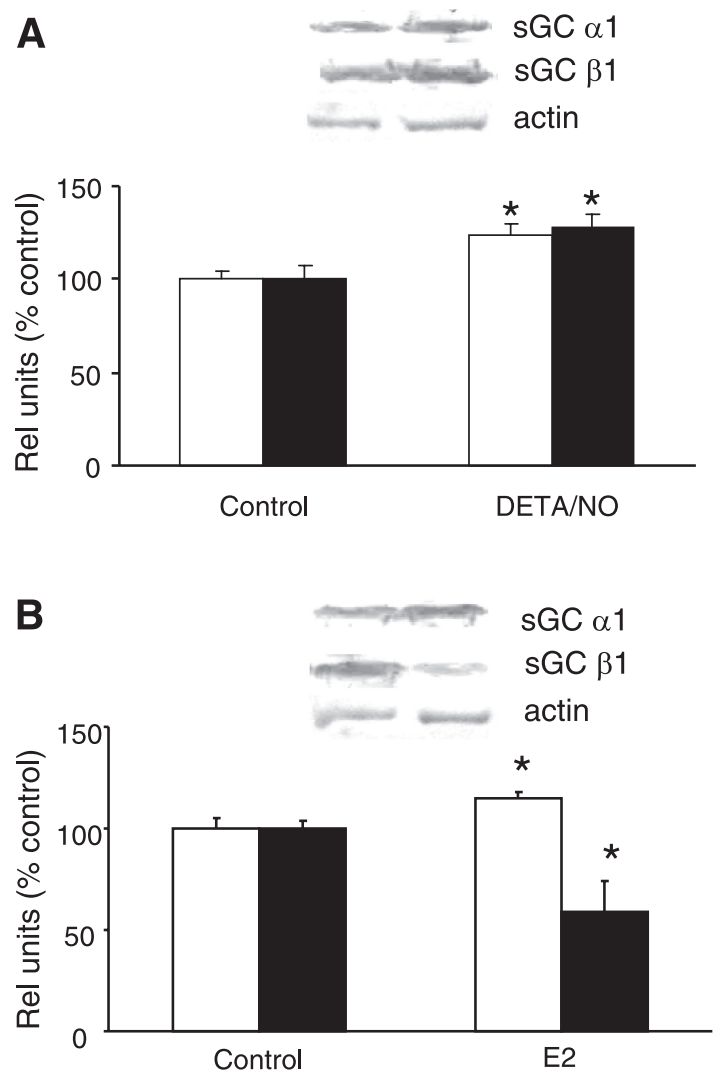

Fig. 5. Short-time nitric oxide exposure upregulated sGC expression, while $\mathrm{E}_{2}$ acute expression differentially affects $\mathrm{sGC}$ subunits in vitro. $A$ : primary pituitary cell cultures from adult intact rats at random stages of estrous cycle were incubated with $0.5 \mathrm{mM}$ DETANONOate, a nitric oxide donor, or with culture medium alone (control) for $6 \mathrm{~h}$. Top: representative Western blot. Bottom: average densitometric values. Bars are media \pm SE of $s G C \alpha_{1}$ (open bars) or sGC $\beta_{1}$ (solid bars) protein levels normalized to actin, as percentage of control $(n=5)$. $B$ : primary pituitary cell cultures from intact, adult rats were incubated with $10^{-9} \mathrm{M} \mathrm{E}_{2}$ or with culture medim alone (control) for $6 \mathrm{~h}$. Top: representative Western blot. Bottom: average densitometric values. Bars are means $\pm \mathrm{SE}$ of $\mathrm{sGC} \alpha_{1}$ (open bars) or $\mathrm{sGC} \beta_{1}$ (solid bars) protein levels normalized to actin, as percentage of control $(n=3)$. $* P<0.05$ vs. respective control, Student's $t$-test. 
fact that the inhibitory $\alpha$ isoform could collaborate to $E_{2}$ transient $\mathrm{sGC}$ inhibition indicates again that $E_{2}$ is acting through multiple pathways. Therefore, our results show that $\mathrm{E}_{2}$ not only decreases $\mathrm{sGC} \beta_{1}$ expression but also stimulates $\mathrm{sGC}_{2 \mathrm{i}}$ expression and by these ways participates in $\mathrm{sGC}$ activity downregulation.

The estrous cycle is a physiological event in which mainly $\mathrm{E}_{2}$ levels, among other hormones, suffer strong changes (27). We studied the expression of both sGC subunits during the estrous cycle to address whether the changes in $\mathrm{E}_{2}$ levels are reflected in the expression pattern of sGC in anterior pituitary gland. Results from this work show that $\mathrm{sGC} \alpha$ - and $\beta$-subunits levels fluctuate through estrous cycle, further supporting a correlation between $\mathrm{E}_{2}$ level changes and $\mathrm{sGC}$ expression pattern. On diestrus, when $\mathrm{E}_{2}$ levels are rising and $\mathrm{NO}$ production is at baseline levels, the expression of $\mathrm{sGC}_{1}$ is the lowest of the entire cycle and, conversely, $\mathrm{sGC} \alpha_{1}$ expression is maximal. Later, on the afternoon of proestrus, when serum $\mathrm{E}_{2}$ levels have drastically fallen and NO production is high, $\mathrm{sGC}_{1}$ expression decreases, while a marked increase in sGC $\beta_{1}$ expression is observed. However, the changes in sGC subunit expression are not identical to that obtained after $E_{2}$ acute administration; there is a shifting towards diestrus where the maximal expression of $\alpha_{1}$ was observed. It is possible that the slow but continuous increase in serum $\mathrm{E}_{2}$ levels, beginning on diestrus I, would be enough to cause the differential changes in the sGC subunits on diestrus.

Our results show that $E_{2}$ treatment enhances sGC $\alpha$ expression, including an augment in $\alpha_{2 \mathrm{i}}$. However, the proportion of $\alpha_{2 i}$ vs. $\alpha_{1}$ expression is very low. Why does $\mathrm{E}_{2}$ augment $\mathrm{sGC} \alpha_{1}$ expression if it would not be involved in sGC enzyme constitution? There is some evidence that strongly suggests that the sGC $\alpha_{1}$ subunit can be individually involved in other processes, independently of cGMP production. In advanced prostate cancer, sGC $\alpha_{1}$ levels are highly correlated with proliferation (5). $\mathrm{E}_{2}$ as a mitogenic factor, as well as a proapoptotic stimulus, drives changes in pituitary cell poblation $(11,16,20) . \mathrm{sGC}_{1}$ levels and timing of pituitary cell proliferation seem to be correlated. $\mathrm{sGC} \alpha_{1}$ expression raises on estrus and diestrus, while proliferation events are taking place, and remains low on proestrus, when the highest levels of apoptotic cells are detected $(6,19,28)$. Thus the putative role of $\alpha_{1}$ in anterior pituitary cell renewal opens a very attractive landscape that is now under investigation.

NO modifies sGC expression on various tissues (15), and NOS expression and activity in anterior pituitary are variable and susceptible of regulation during estrous cycle (17). Here we show that both short- and long-time NO exposition upregulated both sGC subunits at the same extent. Therefore, NO seems not to be involved in the differential changes of the sGC subunit expression during the estrous cycle.

In summary, we provide evidence that sGC activity is downregulated and its subunits are independently affected upon stimulus with exogenous $\mathrm{E}_{2}$ and during the estrous cycle in the rat anterior pituitary gland. These effects appear to be independent of the hypothalamic-pituitary-gonadal axis maturation. The expression of other less active or inhibitory $\mathrm{sGC} \alpha$ isoforms provides a new potential regulation point in $\mathrm{sGC}$ activity. The study of the roles of each subunit of sGC in other processes, in addition to the classical cGMP-producing func- tion, will raise new perspectives and novel pathways to a well-known enzyme.

\section{GRANTS}

This work was supported by research grants from Agencia Nacional de Promoción Científica y Tecnológica (PICT 05-32311), Universidad de Buenos Aires (M025), and Consejo Nacional de Investigaciones Científicas y Técnicas (5536).

\section{REFERENCES}

1. Behrends S, Harteneck C, Schultz G, Koesling D. A variant of the alpha 2 subunit of soluble guanylyl cyclase contains an insert homologous to a region within adenylyl cyclases and functions as a dominant negative protein. J Biol Chem 270: 21109-21113, 1995.

2. Bredt DS, Snyder H. Nitric oxide mediates glutamate-linked enhancement of cGMP levels in the cerebellum. Proc Natl Acad Sci USA 86: 9030-9033, 1989.

3. Budworth J, Meillerais S, Charles I, Powell K. Tissue distribution of the human soluble guanylyl cyclases. Biochem Biophys Res Commun 263, 696-701, 1999.

4. Cabilla JP, Díaz Mdel C, Machiavelli LI, Poliandri AH, Quinteros FA, Lasaga M, Duvilanski BH. 17 $\beta$-Estradiol modifies nitric oxide-sensitive guanylyl cyclase expression and downregulates its activity in rat anterior pituitary gland. Endocrinology 147: 4311-4318, 2006.

5. Cai C, Chen SY, Zheng Z, Omwancha J, Lin MF, Balk SP, Shemshedini L. Androgen regulation of soluble guanylyl cyclase $\alpha 1$ mediates prostate cancer cell proliferation. Oncogene 26: 1606-1615, 2007.

6. Candolfi M, Zaldivar V, Jaita G, Seilicovich A. Anterior pituitary cell renewal during the estrous cycle. Front Horm Res 35: 9-21, 2006.

7. Chen L, Daum G, Fischer JW, Hawkins S, Bochaton-Piallat ML, Gabbiani G, Clowes AW. Loss of expression of the beta subunit of soluble guanylyl cyclase prevents nitric oxide-mediated inhibition of DNA synthesis in smooth muscle cells of old rats. Circ Res 86: 520-525, 2000 .

8. Chen ZJ, Che D, Vetter M, Liu S, Chang CH. 17 $\beta$-Estradiol inhibits soluble guanylate cyclase activity through a protein tyrosine phosphatase in PC12 cells. J Steroid Biochem Mol Biol 78: 451-458, 2001.

9. Cheskis BJ, Greger JG, Nagpal S, Freedman LP. Signaling by estrogens. J Cell Physiol 213: 610-617, 2007.

10. Chu HP, Sarkar G, Etgen AM. Estradiol and progesterone modulate the nitric oxide/cyclic GMP pathway in the hypothalamus of female rats and in GT1-1 cells. Endocrine 24: 177-184, 2004.

11. Ishida M, Takahashi W, Itoh S, Shimodaira S, Maeda S, Arita J. Estrogen actions on lactotroph proliferation are independent of a paracrine interaction with other pituitary cell types: a study using lactotrophenriched cells. Endocrinology 148: 3131-3139, 2007.

12. Koglin M, Behrends S. Native human nitric oxide sensitive guanylyl cyclase: purification and characterization. Biochem Pharm 67: 15791585, 2004.

13. Kostic TS, Andric SA, Stojilkovic SS. Spontaneous and receptor-controlled soluble guanylyl cyclase activity in anterior pituitary cells. Mol Endocrinol 15: 1010-1022, 2001.

14. Krumenacker JS, Hyder SM, Murad F. Estradiol rapidly inhibits soluble guanylyl cyclase expression in rat uterus. Proc Natl Acad Sci USA 98: 717-722, 2001.

15. Krumenacker JS, Hanafy KA, Murad F. Regulation of nitric oxide and soluble guanylyl cyclase. Brain Res Bull 62: 505-515, 2004.

16. Lloyd HM, Meares JD, Jacobi J. Effects of oestrogen and bromocriptine on in vivo secretion and mitosis in prolactin cells. Nature 255: 497-498, 1975.

17. Lozach A, Garrel G, Lerrant Y, Bérault A, Counis R. GnRH-dependent upregulation of nitric oxide synthase I level in pituitary gonadotrophs mediates cGMP elevation during rat proestrus. Mol Cel Endocrinol 143: 43-51, 1998.

18. Lucas KA, Pitari GM, Kazerounian S, Ruiz-Stewart I, Park J, Schulz S, Chepenik KP, Waldman SA. Guanylyl cyclases and signaling by cyclic GMP. Pharm Rev 52: 375-413, 2000.

19. Oishi Y, Okuda M, Takahashi H, Fujii T, Morii S. Cellular proliferation in the anterior pituitary gland of normal adult rats: influences of sex, estrous cycle, and circadian change. Anat Rec 235: 111-120, 1993

20. Pisera D, Candolfi M, Navarra S, Ferraris J, Zaldivar V, Jaita G, Castro MG, Seilicovich A. Estrogens sensitize anterior pituitary 
gland to apoptosis. Am J Physiol Endocrinol Metab 287: E767-E771, 2004.

21. Qian X, Jin L, Lloyd RV. Estrogen downregulates neuronal nitric oxide synthase in rat anterior pituitary cells and GH3 tumors. Endocrine 11: 123-130, 1999.

22. Ritter D, Taylor JF, Hoffman JW, Carnaghi L, Giddings SJ, Zakeri H, Kwok PY. Alternative splicing for the $\alpha 1$ subunit of soluble guanylate cyclase. Biochem J 346: 811-816, 2000.

23. Sharina IG, Krumenacker JS, Martin E, Murad F. Genomic organization of $\alpha 1$ and $\beta 1$ subunits of the mammalian soluble guanylyl cyclase genes. Proc Natl Acad Sci USA 97: 10878-10883, 2000.

24. Shi Q, LaPaglia N, Emanuele NV, Emanuele MA. Castration differentially regulates nitric oxide synthase in the hypothalamus and pituitary. Endocr Res 24: 29-54, 1998.
25. Simpson ER, Misso M, Hewitt KN, Hill RA, Boon WC, Jones ME, Kovacic A, Zhou J, Clyne CD. Estrogen-the good, the bad, and the unexpected. Endocr Rev 26: 322-330, 2005.

26. Smigrodzki R, Levitt $\mathbf{P}$. The alpha 1 subunit of soluble guanylyl cyclase is expressed prenatally in the rat brain. Brain Res Dev Brain Res 97: 226-234, 1996.

27. Smith MS, Freeman ME, Neill JD. The control of progesterone secretion during the estrous cycle and early pseudopregnancy in the rat: prolactin, gonadotropin and steroid levels associated with rescue of the corpus luteum of pseudopregnancy. Endocrinology 96: 219-226, 1975.

28. Yin P, Arita J. Proestrus surge of gonadotropin-releasing hormone secretion inhibits apoptosis of anterior pituitary cells in cycling female rats. Neuroendocrinology 76: 272-282, 2002.



